Counsellia: Jurnal Bimbingan dan Konseling, 10(1), $2020 \mid 54-68$

Copyright @2020 Universitas PGRI Madiun

ISSN: 2088-3072 (Print) / 2477-5886 (Online)

Available online at: http//e-journal.unipma.ac.id/ndex.php/JBK

DOI: 10.25273/counsellia.v10i1.6304

\title{
Teknik Self Management untuk mengurangi perilaku terlambat datang di Sekolah
}

\author{
Anita Dewi Astuti' ${ }^{1)}$, Sri Dwi Lestari ${ }^{2)}$ \\ ${ }^{1}$ FIP, IKIP PGRI Wates, Yogyakarta \\ anitanayata@gmail.com \\ ${ }^{2}$ FIP, IKIP PGRI Wates, Yogyakarta \\ sridwi1996@gmail.com
}

\begin{abstract}
Abstrak
Penelitian ini bertujuan untuk mengetahui keefektifan teknik self management untuk mengurangi perilaku terlambat datang di sekolah. Penelitian ini menggunakan pendekatan kualitatif dengan fokus penelitian perilaku terlambat datang di sekolah. Subjek penelitiannya adalah siswa kelas X SMK Negeri I Panjatan yang ditentukan menggunakan teknik purposive sampling. Ada 3 siswa sebagai subjek penelitian yang ditentukan berdasarkan frekuensi keterlambatan siswa datang di sekolah. Metode pengumpulan data yang digunakan adalah observasi, wawancara dan dokumentasi, sedangkan analisis datanya menggunakan tiga tahapan yaitu: (1) reduksi data, (2) penyajian data, (3) verifikasi atau penarikan kesimpulan. Berdasarkan hasil penelitian dapat disimpulkan bahwa ada perubahan perilaku yang ditandai dengan menurunnya perilaku terlambat siswa antara sebelum dan sesudah diberikan layanan teknik self management.
\end{abstract}

Kata kunci: Self Management, Terlambat Sekolah

\begin{abstract}
This research aims to find out the effectiveness of self management techniques to reduce late arrival behavior at school. This study uses a qualitative approach with a focus on late-arrival behavior research in school. The research subjects were class $X$ student of SMK Negeri I Panjatan who were determined using purposive sampling techniques. There are 3 students as research subjects that are determined based on the frequency of late students coming to school. Data collection methods used are observation, interviews and documentation, while the data analysis use three stages, namely: (1) data reduction, (2) data presentation, (3) verification or drawing conclusions. Based on the results of the study it can be concluded that there is a change in behavior marked by a decrease in late student behavior between before and after self management techniques are provided.
\end{abstract}

Keyword: Self Management, School Late 


\section{PENDAHULUAN}

Sekolah merupakan lembaga tempat menyelenggarakan pendidikan untuk menuntut ilmu diatur dengan ketentuan-ketentuan tertentu yang harus ditaati oleh semua stakeholder di sekolah salah satunya adalah tentang tata tertib sekolah. Siswa sebagai salah satu stakeholder di sekolah mempunyai kewajiban mematuhi tata tertib sekolah untuk menunjang kesuksesan kegiatan belajar mengajar, serta membentuk kepribadian siswa yang bertanggung jawab dan disiplin. Siswa yang disiplin, terdidik, cerdas intelektual, mental maupun spriritual akan memiliki kemampuan bersaing dalam menjalankan tantangan kehidupan di masa mendatang.

Setiap siswa hendaknya dapat berperilaku disiplin dengan memiliki kesadaran menaati tata tertib sesuai peraturan dan norma yang diberlakukan di sekolah, sehingga nantinya berperilaku baik tidak melakukan penyimpangan dan pelanggaran. Bentuk kedisiplinan siswa terhadap tata tertib sekolah adalah tepat waktu datang di sekolah. Terlambat dapat diasumsikan sebagai suatu kegiatan yang tidak dapat dilakukan sebelum waktunya atau tepat pada waktunya (Gata et al., 2019). Tindakan ini merupakan bentuk ketidakmampuan seseorang untuk berada pada suatu tempat dan waktu yang telah disepakati sebelumnya.

Ketentuan yang telah ditetapkan SMK Negeri I Panjatan bahwa jam masuk sekolah pukul 07.00 WIB, jika siswa tiba di sekolah melebihi dari waktu yang ditentukan berarti siswa tersebut dikatakan terlambat. Salah satu aspek terpenting bahwa sekolah itu teratur, terjadwal, dan dapat diprediksi. Setiap harinya siswa beraktivitas sesuai dengan peraturan-peraturan tersebut, karena sebenarnya siswa mengetahui dan memahami tujuan utama berada di sekolah adalah untuk belajar dan dari rutinitas tersebut membantu membiasakan siswa untuk bisa fokus pada pembelajaran. Ketika siswa berulang kali terlambat, rutinitas ini mengganggu dan berdampak pada aktivitas kesehariannya. Terlambat memang bukan termasuk kategori pelanggaran berat, tetapi merupakan salah satu bentuk pelanggaran yang sering dijumpai di sekolah-sekolah meskipun sudah ada jadwal kegiatan belajar mengajar yang disusun dan ditetapkan pihak sekolah (Mulyani, 2017). Ada kecenderungan anak-anak yang sering terlambat mengalami kesulitan dalam beradaptasi dan menguasai rutinitas. Keterlambatan sekolah bagaikan seperti kanker yang dapat menghambat pengembangan dan pencapaian tujuan akademik siswa (Maile \& Olowoyo, 2017).

Perilaku negatif ini memang tidak dilakukan oleh semua siswa, namun ada pula beberapa siswa yang terbiasa terlambat datang di sekolah. Berbagai alasan diutarakan oleh siswa yang memiliki kebiasaan terlambat datang di sekolah antara lain: 1) lokasi antara tempat tinggal dan sekolah jauh; 2) kesulitan dalam transportasi; 3) memiliki aktivitas di rumah; 4) tidak bisa bangun pagi; 5) merasa tidak nyaman dengan situasi sekolah ; 6) kurang berminat terhadap mata pelajaran tertentu; 7) tidak melakukan persiapan termasuk menyelesaikan pekerjaan rumah; 8) lebih tertarik aktivitas di luar sekolah (Prayitno \& Amti, 2004). Siswa yang sering terlambat sekolah kadang menunjukkan semacam pembangkangan. Beberapa alasan di atas juga diutarakan siswa SMK Negeri I Panjatan yang sering terlambat datang di sekolah seperti: jarak dari tempat tinggal ke sekolah jauh, kesulitan transportasi, terlambat bangun, ada kendala di perjalanan misal ban bocor, dan membantu orang tua.

Keterlambatan siswa datang di sekolah merupakan bentuk ketidakdisplinan yang dapat mengganggu proses akademik di sekolah terutama di kelas. Hasil penelitian (Nakpodia \& Dafiaghor, 2011) menunjukkan bahwa keterlambatan ke sekolah memiliki hubungan positif dengan prestasi akademik siswa yang rendah. Hal tersebut menunjukkan bahwa semakin sering siswa terlambat ke sekolah, semakin rendah kinerja akademis mereka. Selain itu, keterlambatan yang sering terjadi di kelas memungkinkan dapat 
menular ke siswa lain. Melihat berbagai permasalahan sebagai akibat dari tindakan siswa yang terlambat datang di sekolah maupun terlambat masuk kelas diperlukan upaya penanganan dari pihak sekolah khususnya dari guru Bimbingan dan Konseling. Guru BK memiliki peranan penting dalam memberikan bantuan kepada siswa sebagai usaha untuk mengembangkan potensi dan bakat yang dimiliki siswa sesuai dengan tugas dan norma guru BK didukung dengan kualitas, kepribadian dan keahlian profesional yang dimilikinya (Kusumawide et al., 2019).

Guru BK dengan beragam layanan yang diberikan kepada siswa bertujuan membantu dan membentuk siswa mandiri memiliki kemampuan mengelola diri secara lebih baik sehingga nantinya dapat menghasilkan sesuatu yang diharapkan. Salah satu layanan yang tepat diberikan kepada siswa dengan kebiasaan sering terlambat datang di sekolah adalah konseling dengan pendekatan behaviorisme. Pendekatan behaviorisme atau sering disebut juga pendekatan tingkah laku menitikberatkan pada aspek kognitif individu dengan beragam teknik, fokus dalam membantu menentukan langkah yang tepat dalam mengubah perilaku seseorang (Walker \& Shea, 2011). Lebih lanjut B.F Skinner mengungkapkan bahwa behavioristik dipandang sebagai respon stimulus baik itu rangsangan eksternal maupun internal, karena tujuan dari terapi ini adalah memodifikasi koneksi-koneksi dan metode-metode stimulus yang menghadirkan respon baik (Willis, 2010). Konseling behaviorisme mempunyai pandangan bahwa pola-pola tingkah laku seseorang dapat dimodifikasi melalui proses pembiasaan dan pemberian reward dengan mengkondisikan atau menciptakan stimulus-stimulus tertentu serta faktor eksternal lainnya yang terlibat.

Konseling behaviorisme memiliki peranan penting dalam mengubah dan membentuk tingkah laku siswa yang baru melalui proses belajar (Muratama, 2018). Berbagai tindakan yang awalnya dikhawatirkan sebagai perilaku yang memiliki kecenderungan mengganggu diri siswa, tetapi setelah diberikan konseling behaviorisme nampak ada perubahan ke arah yang lebih baik. Hal senada juga disampaikan (Prabowo \& Cahyawulan, 2016) yang menyatakan bahwa konseling behaviorisme merupakan teknik konseling yang telah membuktikan keefektifannya dalam memodifikasi berbagai perilaku seseorang, dalam hal ini termasuk mengurangi atau menghilangkan perilaku maladaptif maupun meningkatkan perilaku adaptif. Dari berbagai penelitian sebelumnya menunjukkan hasil bahwa konseling behaviorisme efektif untuk memodifikasi tingkah laku seperti: agresif, membolos, kebiasaan merokok, kecanduan alkohol dan obat-obatan terlarang yang dapat membahayakan kesehatan.

Konseling behavioral dalam prosesnya memiliki beberapa kelebihan dan kekurangan yang lebih ditekankan pada: tingkah laku konseli, ragam permasalahan, bentuk penguatan atau reward yang diberikan dan dukungan dari orang lain yang memiliki pengaruh bagi kehidupan konseli dalam mengubah perilakunya (Sanyata, 2012). Salah satu teknik dalam pendekatan behaviorisme yang tepat untuk mengubah perilaku kebiasaan datang terlambat di sekolah adalah teknik self management. Thompson menegaskan bahwa self management termasuk teknik konseling behavioristik lebih menitikberatkan pada kemauan dan kemampuan konseli untuk mengubah dan mengatur tingkah lakunya sendiri (Amin, 2017).

Hal senada juga disampaikan oleh (Sa'diyah et al., 2017) yang berpendapat bahwa self management bertujuan mempelajari dan memahami perilaku individu dengan mengubah perilaku yang awalnya maladaptif menjadi adaptif. Dalam menerapkan teknik self management terdapat beberapa tahapan salah satunya dikemukakan oleh Sukaji 1983 yang menyebutkan ada tiga tahapan yaitu meliputi: (1) tahap memonitor diri atau observasi diri, (2) tahap evaluasi diri dan (3) tahap pemberian penguatan, penghapusan atau hukuman (Komalasari et al., 2011). Ketiga tahapan tersebut diterapkan dalam proses 
konseling sebagai upaya untuk mengurangi intensitas kebiasaan perilaku terlambat datang di sekolah. Cormier \& Cormier (1985) menegaskan bahwa teknik self management sebagai strategi pengubahan tingkah laku yang mendorong konseli untuk terlibat dan mengarahkan perubahan perilakunya sendiri dengan kombinasi teknik terapeutik. Keterlibatan konseli dalam teknik self management ada pada beberapa atau keseluruhan komponen dasar yaitu: 1) menentukan tingkah laku yang menjadi target perubahan; 2) memantau perilaku; 3) menentukan prosedur yang akan diterapkan; 4) menerapkan prosedur yang telah ditentukan; 5) melakukan evaluasi efektivitas dari prosedur yang telah ditetapkan (Komalasari et al., 2011).

Dalam prosedur penerapan teknik self management konseli diminta melakukan pengamatan dan mencatat perilakunya sendiri baik itu pikiran, perasaaan dan tindakannya serta interaksinya dengan lingkungan. Individu diharapkan dapat mengatur kembali lingkungan, terlibat dalam menentukan stimulus positif diikuti dengan respons yang diinginkan. Dijelaskan pula bahwa di dalam menerapkan teknik self management, konseli memiliki tanggung jawab penuh atas keberhasilan dari sebuah proses konseling. Penekanan dari penerapan teknik self management meskipun konselor dapat melaksanakan tahapan-tahapan self-management untuk klien, namun sebaiknya klienlah yang melaksanakannya sendiri dengan seminimal mungkin bantuan yang diberikan dari konselor (Nurzaakiyah \& Budiman, 2013) sehingga lebih menonjolkan pandangan klien sebagai individu yang dapat belajar atau mengarahkan diri sendiri (Suwanto, 2016). Hal ini ditekankan Wolpe (1963) bahwa peran konselor di dalam konseling behaviorisme adalah bersikap menerima, mencoba memahami diri konseli dan tidak menilai atau mengkritik apapun yang dikemukakan konseli terkait masalah perilaku ketidakdisiplinannya. Self management sebagai upaya untuk memberikan bantuan kepada siswa dalam mengarahkan, merencanakan, mengelola, dan mengendalikan diri mereka dalam melakukan kegiatan, terutama dalam pembelajaran sehingga siswa dapat menggunakan waktu mereka seefisien, dan seefektif mungkin. Kemampuan penguasaan siswa terhadap keterampilan manajemen diri mencerminkan seberapa jauh atau seberapa besar tingkat kemampuan kerja siswa (Gomez, 2017).

Berdasarkan ulasan di atas, peneliti tertarik untuk memberikan tindakan layanan sebagai solusi pemecahan masalah keterlambatan siswa datang di sekolah. Penelitian ini dilakukan berdasarkan asumsi bahwa siswa dengan kebiasaan datang terlambat di sekolah akan menurun frekuensinya apabila diberikan layanan konseling individu menggunakan teknik self management. Berdasarkan asumsi tersebut peneliti tertarik untuk melakukan penelitian dengan judul "Teknik Self Management Untuk Mengurangi Perilaku Terlambat Datang Di Sekolah". Alasan peneliti melakukan penelitian di SMK Negeri I Panjatan bahwa dari hasil observasi yang telah dilakukan sebelumnya masih ditemukan beberapa siswa yang memiliki kebiasaan terlambat datang di sekolah. Hasil yang diharapkan dari penelitian ini adalah dapat mengetahui keefektifan konseling individu dengan teknik self management untuk mengurangi kebiasaan perilaku terlambat datang di sekolah siswa kelas X SMK Negeri I Panjatan Kulon Progo.

\section{METODE PENELITIAN}

\section{Rancangan Penelitian}

Penelitian ini dirancang menggunakan pendekatan kualitatif yang bertujuan memahami fenomena tentang segala sesuatu yang berkaitan dengan yang dialami oleh subyek penelitian (Moleong, 2016). Penelitian kualitatif berusaha menggambarkan sesuai dengan fokus penelitian yaitu perilaku siswa terlambat di sekolah, sehingga nantinya bisa untuk melihat sejauh mana keberhasilan merubah kebiasaan perilaku terlambat datang di sekolah dengan teknik self management. 


\section{Sumber data}

Subyek penelitian adalah sesuatu hal berkaitan dengan sasaran yang dibutuhkan peneliti dapat berupa orang, benda, proses kegiatan, dan tempat. Dalam penelitian ini subyek penelitiannya adalah siswa kelas X SMK Negeri I Panjatan Kulon Progo. Subjek penelitian ditentukan menggunakan teknik purposive sampling berdasarkan pada suatu pertimbangan atau tujuan tertentu yaitu frekuensi keterlambatan siswa yang telah ditetapkan peneliti (Sugiyono, 2015). Sebagai sumber informasi utama dipilih 3 (tiga ) orang siswa dengan inisial AIS, MF dan NA yang memiliki kebiasan datang terlambat di sekolah dengan karakteristik sebagai berikut:

1. Siswa datang di sekolah sesudah jam pelajaran dimulai mungkin ada alasanalasan tertentu yang mengakibatkan terlambat ke sekolah.

2. Siswa menggunakan waktu istirahat melebihi batas waktu yang telah ditetapkan misalnya dengan nongkrong di kantin, di perpustakaan.

3. Siswa sengaja terlambat masuk kelas meskipun sudah mengetahui jadwal pelajaran.

Selain siswa, sebagai sumber informasi tambahan melibatkan juga Kepala Sekolah, Guru BK, dan Wali Kelas.

\section{Teknik Pengumpulan Data}

Data yang diperlukan dalam penelitian dikumpulkan menggunakan lembar observasi dan pedoman wawancara dilengkapi pula dengan dokumentasi. Lembar observasi digunakan untuk mengungkap faktor-faktor atau penyebab perilaku terlambat sekolah, sedangkan untuk pedoman wawancara digunakan untuk menggali data dengan melakukan wawancara kepada kepala sekolah, guru BK, wali kelas dan siswa yang berkaitan dengan pelaksanaan konseling behaviorisme dengan teknik self management.

\section{Teknik Analisis Data}

Data-data yang telah dikumpulkan akan lebih bermanfaat dan bermakna apabila dianalisis. Sebelum data dianalisis terlebih dahulu data tersebut dipilih mana yang sesuai atau relevan dengan tujuan penelitian, sehingga nantinya data yang akan dianalisis harus dipastikan keabsahannya dengan beberapa teknik yaitu: 1) memperpanjang observasi; 2) ketekunan pengamatan dan 3) triangulasi. Data yang terkumpul dalam penelitian ini berbentuk kata-kata (deskripsi) sehingga analisis yang digunakan melalui beberapa tahapan sebagai berikut: 1) reduksi data; 2) penyajian data; 3) verifikasi atau penarikan kesimpulan (Sugiyono, 2015).

\section{HASIL DAN PEMBAHASAN}

\section{Hasil Penelitian}

Hasil penelitian ini menjelaskan tahapan-tahapan yang dilakukan selama proses konseling untuk mengurangi frekuensi kebiasaan siswa terlambat datang di sekolah dengan menerapkan tahapan-tahapan dalam teknik self management.

\section{Reduksi Data}

Reduksi data dalam penelitian ini dilakukan sebagai bentuk analisis untuk mempertajam data hasil penelitian. Reduksi data dilakukan dengan mengklasifikasikan, mengarahkan, memilih data dengan cara membuang data yang tidak diperlukan serta mengorganisasikan data dengan sedetail mungkin sehingga nantinya dapat diverifikasi dan diambil kesimpulan. Data yang direduksi dalam penelitian ini bersumber pada semua data yang berhasil dikumpulkan selama penelitian berlangsung baik dari hasil wawancara, observasi maupun dokumentasi. Data yang terkumpul kemudian dianalisis dan diklasifikasikan sesuai rumusan masalah. Data yang dihasilkan pada tahap reduksi data 
berupa rangkuman dan deskripsi yang menggambarkan perilaku terlambat siswa serta gambaran selama proses konseling sesuai tahapan-tahapan teknik self management yang disajikan dalam tahap berikutnya yaitu pada tahap penyajian data.

\section{Penyajian Data}

a. Melakukan assesment perilaku terlambat sekolah siswa kelas X SMK N 1 Panjatan.

Cara yang dilakukan peneliti dalam assesment perilaku terlambat datang di sekolah adalah melalui wawancara, observasi dan dokumentasi yang bersumber dari guru BK. Peneliti mewawancarai guru BK, dan wali kelas, sedangkan data yang diperoleh dari siswa bersumber pada proses konseling individu dengan teknik self management kepada siswa yang memiliki masalah terlambat sekolah dengan tiga indikator yang telah ditentukan di awal. Ketiga indikator tersebut dapat dijabarkan dalam hasil wawancara sebagai berikut:

1) Datang di sekolah melebihi jadwal pelajaran yang ditentukan.

Hasil wawancara kepada guru BK, telah menemukan siswa dengan gejala sering terlambat mengikuti pelajaran dari jadwal yang telah ditentukan. Hal ini dibuktikan dengan adanya informasi dan keluhan dari wali kelas yang disampaikan kepada guru BK. Informasi yang ditambahkan oleh Guru BK bahwa gejala siswa terlambat mengikuti pelajaran dari jadwal yang telah ditentukan karena datang lebih dari jam 07.00 dan dari hasil pengamatan yang dilakukan secara berkala menunjukkan bahwa siswa dengan frekuensi terlambat tinggi, akhirnya nantinya tidak semangat dalam mengikuti pelajaran. Hasil observasi dan wawancara kepada siswa AIS, diperoleh informasi bahwa AIS terlambat mengikuti pelajaran karena bangun kesiangan selain itu juga merasa terbebani dengan banyaknya tugas (PR) pemberian guru. Berbeda dengan informasi yang diperoleh dari siswa MF, dia sering terlambat mengikuti pelajaran karena terlebih dahulu membantu ibunya, sedangkan siswa NA terlambat mengikuti pelajaran disebabkan tidak memiliki kendaraan pribadi sehingga kesulitan transportasi. Berdasarkan data observasi dan wawancara di atas dapat disimpulkan bahwa gejala siswa sering datang terlambat melebihi jadwal yang ditentukan karena bangun kesiangan, banyak tugas, kesulitan transportasi.

2) Gejala menggunakan waktu istirahat melebihi waktu yang ditentukan.

Hasil wawancara yang dilakukan peneliti kepada guru BK bahwa, gejala menggunakan waktu istirahat melebihi waktu yang ditentukan karena kebiasaan siswa cuek atau tidak peduli ketika sudah ada tanda bel masuk. Sejalan dengan hasil wawancara peneliti kepada wali kelas didapat informasi bahwa siswa menganggap hal tersebut biasa saja ketika menggunakan waktu istirahat melebihi waktu yang ditentukan.

Hasil observasi dan wawancara dengan siswa AIS yang tidak bisa memanfaatkan waktu istirahat dengan baik, diperoleh informasi bahwa AIS lebih senang menyendiri, nongkrong di area luar sekolah hal itu disebabkan karena tidak menyukai guru mata pelajaran tertentu. Hal serupa disampaikan siswa MF alasan menggunakan waktu istirahat melebihi waktu yang ditentukan karena dia tidak menyukai guru mata pelajaran karena merasa bosan dengan cara mengajarnya. Berbeda dengan yang dinyatakan siswa NA, gejala memakai waktu istirahat melebihi waktu yang ditentukan karena merasa cocok dan asyik ngobrol dengan teman. Dari hasil wawancara dan observasi kepada semua subjek penelitian dapat disimpulkan bahwa gejala 
menggunakan waktu istirahat melebihi waktu yang ditentukan adalah siswa lebih senang nongkrong di luar sekolah dari pada mengikuti pelajaran, tidak tertarik dengan guru mata pelajaran sehingga cenderung bersikap cuek atau tidak peduli dengan orang lain.

3) Gejala sengaja terlambat masuk kelas meskipun tahu jam pelajaran sudah mulai.

Dari wawancara peneliti dengan guru $\mathrm{BK}$, gejala sengaja terlambat masuk kelas meskipun tahu jam pelajaran sudah mulai yaitu siswa menunjukkan perilaku kurang sopan dan dia seenaknya saja ketika masuk kelas. Hal serupa juga diungkapkan wali kelas, bahwa siswa yang terlambat masuk kelas akhirnya nanti menunjukkan sikap kurang semangat dalam mengikuti pelajaran.

Hasil observasi dan wawancara peneliti dengan siswa AIS memperoleh informasi bahwa penyebab terlambat masuk kelas karena tidak menyukai suasana kelas dan tidak tertarik dengan salah satu mata pelajaran. Hal tersebut juga diungkapkan siswa MF, faktor penyebab terlambat masuk kelas yaitu merasa malas mengikuti pelajaran karena tidak mengerjakan PR. Sedangkan siswa NA, mengatakan alasan terlambat masuk kelas meskipun tahu jam pelajaran sudah mulai yaitu karena sudah menjadi kebiasaan lebih asyik dengan kegiatan organisasi. Berdasarkan keterangan dari semua sumber informasi dapat disimpulkan bahwa, gejala terlambat masuk kelas meskipun tahu jam pelajaran sudah mulai yaitu karena tidak siap mengikuti pelajaran disebabkan tidak mengerjakan PR, tidak menyukai suasana kelas, dan lebih senang mengikuti kegiatan organisasi.

b. Cara melaksanakan goal setting perilaku terlambat sekolah

Goal setting dilakukan dengan menetapkan tujuan untuk mengubah gejalagejala negatif yang menyebabkan siswa memiliki kebiasaaan terlambat datang di sekolah. Tujuan tersebut ditentukan sesuai masing-masing gejala yang muncul pada diri siswa.

1) Tujuan agar siswa tiba di sekolah tepat waktu

Hasil wawancara yang dilakukan oleh peneliti dengan guru BK perlu menetapkan tujuan agar siswa mempunyai tanggung jawab berupa kedisiplinan. Hal serupa juga dinyatakan wali kelas, siswa harus memiliki kedisiplinan yang baik karena disiplin sebagai wujud sikap menghargai, menghormati, taat dan patuh terhadap peraturan yang ada.

Dari hasil observasi dan wawancara dengan siswa AIS, tujuan yang ditetapkan agar tidak bangun kesiangan adalah dengan cara membunyikan jam alarm. Lain halnya dengan tujuan yang ditetapkan siswa MF agar mempunyai kemampuan membagi waktunya sehingga tetap bisa membantu ibunya, tetapi tidak terlambat datang di sekolah. Siswa NA menetapkan tujuan agar tidak terlambat datang di sekolah dengan berusaha bangun pagi agar mendapatkan tumpangan transportasi umum. Berdasarkan keterangan di atas dapat disimpulkan bahwa beragam tujuan yang ditetapkan ketiga siswa agar tidak terlambat datang di sekolah bermaksud agar siswa berperilaku secara positif, serta membentuk rasa tangung jawab terhadap kedisiplinan.

2) Tujuan agar siswa bijak dalam menggunakan waktu istirahat

Hasil wawancara dengan guru BK, perlu menetapkan tujuan agar siswa bijak dalam menggunakan waktu istirahat dan mampu memanfaatkan waktu 
yang ada untuk digunakan sebaik mungkin. Hal serupa diungkapkan oleh guru wali kelas, ditetapkannya tujuan agar siswa bijak dalam menggunakan waktu istirahat sebagai upaya siswa dapat belajar bagaimana menghargai waktu. Dari hasil observasi dan wawancara denga ketiga siswa, ditetapkannya tujuan agar siswa bijak dalam menggunakan waktu istirahat sehingga nantinya dapat memanfaatkan waktu istirahat dengan melakukan hal-hal yang positif, dapat memupuk rasa suka terhadap guru mata pelajaran tertantu.

3) Tujuan agar siswa tidak terlambat masuk kelas meskipun tahu jam pelajaran sudah mulai

Berdasarkan wawancara dengan guru BK, tujuannya agar siswa mempunyai kemampuan untuk bertanggung jawab terhadap segala sesuatu. Wali kelas juga menambahkan, tujuannya agar siswa mempunyai kemampuan untuk memanagement waktu dengan sebaik mungkin. Hasil observasi dan wawancara peneliti dengan siswa AIS, tujuannya agar siswa menyadari bahwa perilaku melambatkan-lambatkan masuk kelas merupakan hal yang merugikan. Ditambahkan oleh siswa MF bahwa tujuanya agar siswa dapat menyikapi dan memanfaatkan waktu dengan sebaik mungkin. Siswa NA, juga menyatakan tujuannya agar siswa dapat menyikapi dan memanfaatkan waktu dengan sebaik mungkin.

Berdasarkan keterangan di atas maka dapat disimpulkan bahwa, tujuan siswa tidak terlambat masuk kelas meskipun tahu jam pelajaran sudah mulai agar siswa dapat menyikapi dan menggunakan waktu sebaik mungkin.

c. Cara melaksanakan technique implementation self management perilaku terlambat sekolah

Tahap technique implementation merupakan tahap penerapan teknik self management untuk mengurangi kebiasaan perilaku terlambat datang di sekolah. Sebelum teknik self management diterapkan kepada AIS, MF, dan NA terlebih dahulu akan disajikan hasil observasi yang menggambarkan perilaku ketiga siswa dengan kebiasaan terlambat datang di sekolah berikut datanya.

Tabel 1. Data Perilaku Terlambat Siswa Sebelum Diberikan Tindakan Teknik Self Management

\begin{tabular}{cccccc}
\hline & & \multicolumn{3}{c}{ Aspek Yang Diobservasi } & \\
\cline { 3 - 5 } No & Nama & $\begin{array}{c}\text { Datang di } \\
\text { sekolah melebihi } \\
\text { jadwal pelajaran } \\
\text { yang ditentukan. }\end{array}$ & $\begin{array}{c}\text { Menggunakan } \\
\text { waktu istirahat } \\
\text { melebihi waktu } \\
\text { yang ditentukan }\end{array}$ & $\begin{array}{c}\text { Sengaja terlambat } \\
\text { masuk kelas } \\
\text { meskipun tahu } \\
\text { pelajaran sudah } \\
\text { dimulai }\end{array}$ & Total Skor \\
\hline 1 & AIS & 10 & 11 & 11 & 32 (Tinggi) \\
\hline 2 & MF & 10 & 10 & 11 & 31 (Tinggi) \\
\hline 3 & NA & 13 & 10 & 11 & 34 (Tinggi) \\
\hline
\end{tabular}

Berdasarkan tabel 1 di atas diketahui bahwa perilaku siswa terlambat datang di sekolah dari ketiga siswa masuk dalam kategori tinggi yaitu AIS dengan skor 32 (73\%); MF dengan skor 31 (70 \%); dan NA dengan skor 34 (77 $\%)$. Data tersebut mengartikan bahwa masih tingginya gejala-gejala penyebab siswa terlambat datang di sekolah sehingga memerlukan tindakan konseling sebagai upaya untuk mengurangi tingkat perilaku terlambat di sekolah.

Menurut guru BK, teknik konseling yang diterapkan dalam mengatasi perilaku terlambat datang di sekolah yaitu dengan strategi mengontrol diri agar siswa dapat mencapai tujuan yang diinginkan secara positif dan 
mempertimbangkan banyak hal agar dapat lebih baik. Misalnya siswa yang sering terlambat datang di sekolah lalu dia diberi penjelasan agar dapat mengatur waktu sehingga dapat bangun pagi dan pergi ke sekolah on time. Setelah siswa berhasil mengubah perilaku yang negatif menjadi positif kemudian diberikan reward berupa pujian agar siswa dapat mempertahankan perilaku tersebut. Wali kelas, juga menambahkan teknik konseling yang diterapkan dalam mengatasi perilaku terlambat datang di sekolah yaitu menggunakan teknik pembentukan tingkah laku dan memberikan nasehat-nasehat tentang mengatur diri supaya siswa dapat bertingkah laku sesuai dengan yang diharapkan.

Hasil wawancara dan observasi dengan siswa AIS, strategi yang dilakukan yaitu berusaha agar tetap berangkat tepat waktu serta berperilaku disiplin dengan cara membunyikan alarm dan menghilangkan perilaku yang negatif. Penentuan strategi juga dilakukan siswa MF sesuai dengan tujuan yang telah ditentukan dirinya sendiri yaitu menghilangkan gejala-gejala penyebab perilaku terlambat datang di sekolah serta memangement waktu. Pengaturan waktu dilakukan dengan cara membuat jadwal aktivitas kesehariannya dengan harapan dapat bangun lebih pagi lagi dari biasanya agar tetap bisa membantu ibunya terlebih dahulu. Lain halnya siswa NA, strategi yang dilakukan yaitu dengan cara membatasi waktu nongkrong di luar kelas serta tidak bertele-tele dalam mengikuti organisasi sehingga dapat masuk kelas secara tepat waktu, mengikuti nasihat, memupuk kembali motivasi mengikuti pelajaran sehingga nantinya bisa membagi waktu dengan baik.

Dari hasil wawancara dan observasi peneliti dengan guru BK, wali kelas dan ketiga siswa dapat disimpulkan bahwa strategi yang tepat dan efektif untuk mengurangi perilaku terlambat datang di sekolah adalah dengan teknik self management. Hal ini dibuktikan dari hasil observasi perubahan perilaku siswa AIS, MF, dan NA setelah diberikan tindakan dengan teknik self management yang akan disajikan dalam tabel berikut.

Tabel 2. Data Perilaku Terlambat Siswa Setelah Diberikan Tindakan Teknik Self Management

\begin{tabular}{|c|c|c|c|c|c|}
\hline \multirow[b]{2}{*}{ No } & \multirow[b]{2}{*}{ Nama } & \multicolumn{3}{|c|}{ Aspek Yang Diobservasi } & \multirow[b]{2}{*}{ Total Skor } \\
\hline & & $\begin{array}{c}\text { Datang di sekolah } \\
\text { melebihi jadwal } \\
\text { pelajaran yang } \\
\text { ditentukan. }\end{array}$ & $\begin{array}{l}\text { Mengggunakan } \\
\text { waktu istirahat } \\
\text { melebihi waktu } \\
\text { yang ditentukan }\end{array}$ & $\begin{array}{c}\text { Sengaja terlambat } \\
\text { masuk kelas } \\
\text { meskipun tahu jam } \\
\text { pelajaran sudah mulai }\end{array}$ & \\
\hline 1 & AIS & 7 & 5 & 8 & 20 (sedang) \\
\hline 2 & $\mathrm{MF}$ & 8 & 5 & 8 & 21 (sedang) \\
\hline 3 & NA & 8 & 4 & 9 & 21 (sedang) \\
\hline
\end{tabular}

Berdasarkan data tabel 2 di atas diketahui bahwa dari ketiga siswa masuk dalam kategori sedang yaitu AIS dengan skor 20 (45 \%); MF dengan skor 21 (48 $\%)$; dan NA dengan skor 21 (48 \%). Data tersebut mengandung makna bahwa ada perubahan perilaku siswa setelah diberikan konseling dengan teknik self management yang ditandai dengan menurunnya gejala-gejala penyebab perilaku terlambat siswa.

d. Cara melaksanakan evaluation termination perilaku terlambat sekolah

Tahap evaluasi ini dilakukan untuk mengetahui keberhasilan konseling individu dengan teknik self management melalui proses wawancara kepada guru BK, dan wali kelas serta melihat hasil perubahan tingkah laku siswa setelah diberikan tindakan dengan teknik self management. Evaluasi dilakukan untuk 
mengetahui seberapa besar perubahan siswa terhadap kedisiplinan menaati tata tertib sekolah.

Menurut guru BK, setelah diberikan layanan konseling individu dengan teknik self management ada perubahan perilaku yang ditunjukkan siswa menjadi lebih baik. Ditambahkan pula dari hasil pengamatan guru BK dan laporan dari wali kelas yang mengatakan bahwa setelah diberikan tindakan siswa sudah bisa datang on time, walaupun masih ada beberapa gejala yang diulangi lagi. Menurut wali kelas, setelah diberi layanan konseling siswa menunjukkan perilaku menjadi lebih baik dari sebelumnya serta siswa dapat mengungkapkan permasalahannya secara terbuka. Berikut akan disajikan grafik yang menunjukkan perubahan berkurangnya frekuensi perilaku terlambat siswa setelah diberikan tindakan dengan teknik self management.

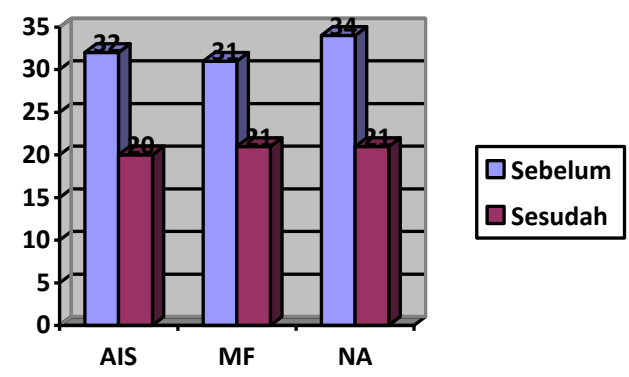

Grafik 1. Data Skor Siswa Sebelum dan Sesudah Diberikan Tindakan Teknik Self Management

Berdasarkan grafik 1 di atas, skor ketiga siswa sebelum diberikan layanan teknik self management menunjukkan kategori frekuensi keterlambatannya tinggi. Setelah diberikan layanan konseling dengan teknik self management dari ketiga siswa AIS, MF, dan NA menunjukkan perubahan positif yang ditandai dengan menurunnya skor keterlambatan siswa. Kesimpulan yang dapat diambil dari hasil penelitian ini bahwa penerapan teknik self management efektif untuk mengurangi perilaku kebiasaan terlambat siswa. Hal ini dikuatkan dari data di atas bahwa masing-masing siswa mengalami penurunan skor keterlambatan datang di sekolah antara 10 sampai 13. Jika di rata-rata dari ketiga siswa tingkat penurunan keterlambatan siswa datang di sekolah sebesar $26 \%$ dari sebelum tindakan sebesar $73 \%$ dan sesudah tindakan sebesar $47 \%$.

\section{Verifikasi}

Verifikasi dalam penelitian ini dilakukan setelah tahap reduksi data selesai. Langkah yang dilakukan pada tahap verifikasi ini adalah dengan melakukan pengecekan kembali dari data yang telah dikumpulkan untuk mengetahui keabsahan datanya. Sebagai upaya untuk mendapatkan keabsahan data dalam penelitian ini, peneliti mendengarkan kembali hasil wawancara dengan semua sumber informasi ( kepala sekolah, guru BK, wali kelas, siswa) dan mencocokkan kembali dengan hasil wawancara yang telah ditulis oleh peneliti. Selain itu peneliti juga melakukan pengecekan ulang dari hasil observasi dan dokumentasi yang terkumpul sebelumnya. Dari hasil verifikasi kemudian dapat dilakukan analisis deskriptif. Analisis deskriptif dilakukan dengan menggambarkan keadaan atau fenomena terkait fokus penelitian yaitu perilaku terlambat siswa dengan kata-kata atau kalimat kemudian dipisahkan menurut kategori untuk mendapatkan kesimpulan sesuai tujuan penelitian. Pengambilan kesimpulan sebagai tahap terakhir untuk kesempurnaan dari sebuah 
penelitian serta mempertegas dengan kajian yang bersumber dari penelitian sebelumnya.

\section{Pembahasan}

Berdasarkan hasil penelitian di atas peneliti menemukan jawaban tentang bagaimana keefektifan teknik self management untuk mengurangi kebiasaan perilaku terlambat datang di sekolah siswa kelas X di SMK Negeri I Panjatan Kulon Progo melalui beberapa tahapan yaitu: Tahap pertama yaitu assessment, dalam melaksanakan assesment untuk mengurangi perilaku terlambat datang di sekolah yaitu dengan mencari penyebab atau gejala terlambat melalui wawancara dan observasi kepada guru BK, wali kelas, dan siswa. Hasil yang diperoleh yaitu bahwa siswa yang mengalami terlambat sekolah ditunjukkan dengan gejala sering datang di sekolah melebihi jadwal pelajaran yang ditentukan, menggunakan waktu istirahat melebihi waktu yang ditentukan, dan sengaja terlambat masuk kelas meskipun tahu jam pelajaran sudah mulai. Berbagai penyebab siswa datang terlambat di sekolah karena adanya pengaruh lingkungan, adanya konflik dengan teman, kebiasaan di rumah, dan sikap yang tidak pasti dari masing-masing anak.

Penyebab atau gejala yang diperoleh dari hasil penelitian ini sesuai dengan pendapatnya (Prayitno \& Amti, 2004) yang menyatakan secara lebih rinci gambaran dari perilaku terlambat sekolah meliputi: 1) sampai di sekolah setelah jam pelajaran dimulai; 2) menggunakan waktu istirahat melebihi waktu yang telah ditentukan.; 3) sengaja terlambat masuk kelas meskipun sudah mengetahui jam pelajaran sudah dimulai. Siswa yang memiliki kebiasaan datang terlambat biasanya mengungkapkan alasan rasional seperti kemacetan lalu lintas, membantu orang tua, atau tanggung jawab pekerjaan di rumah yang telah menghambat mereka tepat waktu datang di sekolah (Bataineh, 2014).

Keterlambatan sering dianggap tidak pantas dalam berbagai situasi, tetapi tidak demikian halnya dalam situasi lain. Dalam beberapa keadaan umum, aturan tentang keterlambatan mungkin implisit terkadang kabur selain itu berkaitan dengan norma sosial lebih khusus lagi norma budaya (Gelfand \& Jackson, 2016). Dalam konteks pendidikan keterlambatan mengacu pada situasi di mana seorang siswa sampai ke sekolah melebihi dari waktu yang telah ditentukan (Adegunju et al., 2019). Sesekali datang terlambat ke sekolah tidak akan menyebabkan gangguan besar. Namun keterlambatan yang terlalu sering bahkan yang telah melekat menjadi kebiasaan akan berdampak pada pengalaman pendidikan anak secara keseluruhan. Setelah mengetahui gejala-gejala penyebab perilaku terlambat siswa, maka dilanjutkan pada tahap kedua yaitu goal setting.

Tahap kedua ini merupakan salah satu tahapan dalam teknik self management yaitu menentukan target behavior yang akan ditingkatkan atau diturunkan (Thompson, 2016). Dalam menerapkan teknik self management siswa diarahkan untuk menentukan target perilaku yang ingin mereka ubah. Penerapan teknik self management berarti mendorong diri sendiri untuk lebih baik dan berfikir kedepan dalam mengatur semua unsur yang terkait dengan kehidupan pribadi, memiliki kemampuan mengendalikan sesuatu untuk mencapai hal-hal yang baik (Gie, 2000). Dari penelitian ini membuktikan bahwa penerapan teknik self management dapat mengubah perilaku siswa dengan berperilaku positif, mengurangi gejala-gejala yang menjadi penyebab perilaku terlambat siswa sehingga sadar bahwa terlambat sekolah dapat merugikan diri sendiri.

Tahap ketiga yaitu technique implementation, dalam tahap ini teknik yang diterapkan untuk mengurangi perilaku terlambat datang di sekolah yaitu teknik self management dengan terlebih dahulu menentukan tujuan yang akan dicapai. Tujuan tersebut disepakati bersama antara konselor dengan konseli. Konselor memberikan arahan kepada konseli dalam menetapkan tujuan, sedangkan konseli terlibat aktif selama proses konseling dan memiliki tugas mengontrol pelaksanaan program sesuai tujuan yang telah 
ditetapkan di awal (Nurazmi \& Kurniawan, 2016). Adanya kerjasama yang baik antara konselor dan konseli mendukung siswa dapat mengontrol diri mencapai tujuan yang diinginkan secara positif dan mempertimbangkan hal-hal lain agar lebih baik.

Tahap keempat yaitu evaluation termination, yaitu dengan mengevaluasi keberhasilan pelaksanaan konseling individu dengan teknik self management kepada guru BK, wali kelas, dan siswa. Tahap evaluasi ini dilakukan dengan cara konseli membandingkan antara hasil catatan dengan target perilaku yang telah ditetapkan oleh konseli (Komalasari et al., 2011). Hasil evaluasi tersebut digunakan untuk mengetahui apakah program yang telah dilaksanakan berhasil atau belum, jika belum berhasil maka perlu dilakukan peninjauan kembali apakah sasaran perilaku yang ditetapkan memiliki harapan yang terlalu tinggi, perilaku yang tidak sesuai, atau pemberian penguatan (reward) yang tidak tepat. Berdasarkan hasil penelitian ini membuktikan bahwa program yang ditentukan telah sesuai dengan target yang ditandai dengan menurunnya perilaku terlambat siswa.

Penelitian ini menguatkan hasil penelitian yang telah dilakukan sebelumnya bahwa teknik self management efektif untuk mengurangi perilaku bolos siswa (Latifah, 2019). Penelitian Latifah ini menggunakan rancangan penelitian quasi eksperimental dengan desain One Group Pretest-Posttest sebagai subjeknya adalah adalah siswa kelas VIII Sekolah Menengah Muhammadiyah 4 Singosari Malang sebanyak tujuh siswa dengan inisial AB, MA, AA, SR, NZ, SZ, NP. Teknik pengumpulan datanya menggunakan skala perilaku membolos siswa dan pedoman observasi yan digunakan untuk mengukur tingkat perilaku bolos siswa sebelum tindakan dan setelah tindakan, sedangkan untuk pedoman eksperimental digunakan untuk menguji desain penelitian yang telah dirancang. Tahap terakhir dalam sebuah penelitian adalah melakukan analisis data yang dilakukan menggunakan uji Wilcoxon.

Berdasarkan hasil penelitian ini diketahui bahwa bahwa perilaku membolos untuk pre test masuk dalam kategori tinggi dengan skor 31,2 sedangkan untuk hasil post test masuk dalam kategori sedang dengan skor 17. Dari hasil uji Wilcoxon didapat signifikansi $0,018<0,05$ menunjukkan bahwa perilaku membolos siswa berkurang setelah diberikan tindakan dengan teknik sef management. Dilihat dari pendekatan penelitian ada perbedaan antara penelitian sebelumnya dengan penelitian ini, dimana pada penelitian sebelumnya menggunakan pendekatan kuantitatif sedangkan pada penelitian ini menggunakan pendekatan kualitatif. Perbedaan kedua terletak pada objek atau fokus penelitian. Pada penelitian sebelumnya mengambil objek penelitian perilaku membolos siswa sedangkan pada penelitian ini mengambil fokus penelitian perilaku terlambat siswa dimana keduanya termasuk bentuk ketidakdisiplinan terhadap tata tertib di sekolah.

Penelitian lainnya juga membuktikan bahwa teknik self management pada pelaksanaan bimbingan kelompok untuk meningkatkan kemandirian belajar siswa (Wahyaningrum et al., 2017). Penelitian ini menggunakan desain eksperimen Treatment by Subject Design, dan teknik pengambilan sampel menggunakan simple random sampling. Dalam penelitian ini subjek penelitian berjumlah 12 siswa yang berasal dari kelas VIII, sedangkan instrumen pengumpulan data menggunakan skala likert kemandirian belajar dan teknik analisis datanya mengggunakan t-test. Dari hasil uji t-test diperoleh nilai $t_{\text {hitung }}$ sebesar 26,941 dan $t_{\text {tabel }}$ sebesar 2,042, sehingga $t_{\text {hitung }}>t_{\text {tabel }}$. Berdasarkan hasil penelitian tersebut menunjukkan keefektifan teknik self management yang dibuktikan dengan meningkatnya kemandirian belajar siswa.

Penelitian sebelumnya yang sejalan dengan penelitian ini menunjukkan bahwa teknik self management efektif untuk mengurangi perilaku terlambat masuk sekolah (Alamri, 2015). Penelitian tersebut menggunakan layanan bimbingan kelompok dengan desain penelitian tindakan bimbingan dan konseling yang dirancang dalam dua siklus, 
masing-masing siklus terdiri dari tiga kali pertemuan, sedangkan dalam penelitian ini menggunakan desain penelitian kualitatif. Dilihat dari prosesnya dalam penelitian sebelumnya terlihat lebih rinci dan menggambarkan perubahan secara mendetail dari siklus pertama ke siklus berikutnya yang dinyatakan dalam bentuk angka sehingga lebih jelas, sedangkan dalam penelitian ini dilihat dari prosesnya berusaha memperlihatkan tahapan-tahapan dan perubahan secara jelas dari penerapan teknik self management yang dinyatakan dalam bentuk kata-kata (deskripsi).

Berdasarkan beberapa hasil penelitian sebelumnya telah membuktikan bahwa teknik self management efektif untuk mengatasi berbagai permasalahan. Dari hasil penelitian ini menegaskan kembali bahwa penerapan teknik self management efektif untuk mengurangi kebiasaan perilaku terlambat datang di sekolah. Pemanfaatan layanan konseling individu dengan teknik self managemet telah berhasil mengubah perilakunya menjadi individu yang lebih bertanggung jawab dan memiliki kesadaran dalam menaati tata tertib.

\section{SIMPULAN}

Berdasarkan hasil penelitian dari pelaksanaan konseling individu dengan teknik self management dapat disimpulkan bahwa penerapan teknik self management efektif untuk mengurangi perilaku terlambat siswa kelas X SMK Negeri I Panjatan Kulon Progo. Dari hasil penelitian ini saran yang dapat disampaikan, hendaknya guru Bimbingan dan Konseling dapat memberikan layanan kepada siswa dengan menerapkan beragam teknik salah satunya teknik self management untuk meningkatkan rasa tanggung jawab dan kesadaran siswa dalam menaati tata tertib sekolah. Kepada kepala sekolah diharapkan dapat memberikan dukungan dan fasilitas pelatihan self management kepada semua guru mata pelajaran, sehingga nantinya pelaksanaan self management dapat optimal dalam kegiatan belajar mengajar di kelas dan dengan harapan siswa menjadi lebih bertanggung jawab dalam mengikuti setiap mata pelajaran. Bagi peneliti berikutnya yang hendak mengkaji atau meneliti self management diharapkan dapat melaksanakan penelitian dengan rancangan dan desain yang lebih baik lagi, dapat memberikan tahapan-tahapan yang lebih jelas disertai materi yang lebih lengkap dan menarik, sehingga siswa dapat mengimplementasikan self management dalam kegiatan belajar maupun dalam kehidupan sehari-hari.

\section{UCAPAN TERIMAKASIH}

Ucapan terima kasih disampaikan kepada semua pihak dan SMK Negeri I Panjatan Kulon Progo baik itu kepala sekolah, guru-guru dan siswa yang telah berkontribusi memberikan bantuan dalam penelitian ini, sehingga penelitian ini dapat terlaksana dengan lancar.

\section{DAFTAR PUSTAKA}

Adegunju, K. A., Ola-Alani, E. K., \& Agubosi, L. A. (2019). Factors Responsible for Students' Lateness to School as Expressed by Nigerian Teachers in Elementary Schools. Mimbar Sekolah Dasar, 6(2), 185-197. https://doi.org/10.17509/mimbar-sd.v6i2.17040

Alamri, N. (2015). Layanan Bimbingan Kelompok Dengan Teknik Self Management Untuk Mengurangi Perilaku Terlambat Masuk Sekolah (Studi Pada Siswa Kelas X SMA 1 Gebog Tahun 2014/2015). Jurnal Konseling Gusjigang, 1(1). https://doi.org/10.24176/jkg.v1i1.259

Amin, Z. N. (2017). Portofolio Teknik-Teknik Konseling (teori dan contoh aplikasi penerapan). Unnes, May. 
Bataineh, M. Z. (2014). A Review of Factors associated with Student 's Lateness Behavior and Dealing Strategies. Journal of Education and Practice, 5(2), 1-7.

Cormier, W. H., \& Cormier, L. S. (1985). Interviewing Strategies For Helpers Fundamental Skill and Behavioral Interventions. 2 ed. Monterey. California: Publishing Company.

Gata, W., Grand, G., Fatmasari, R., Baharuddin, B., Patras, Y. E., Hidayat, R., Tohari, S., \& Wardhani, N. K. (2019). Prediction of Teachers' Lateness Factors Coming to School Using C4.5, Random Tree, Random Forest Algorithm. 258 (Icream 2018), 161-166. https://doi.org/10.2991/icream-18.2019.34

Gelfand, M. J., \& Jackson, J. C. (2016). From one mind to many: The emerging science of cultural norms. Current Opinion in Psychology, 8, 175-181. https://doi.org/10.1016/j.copsyc.2015.11.002

Gie, T. L. (2000). Cara Belajar Yang Baik Bagi Mahasiswa. Yogyakarta: Gadjah Mada University Press.

Gomez, S. J. (2017). Self-Management Skills of Management Graduates. International Journal of Research in Management \& Business Studies, 4(3), 40-45. http://ijrmbs.com/vol4issue3/savilene.pdf

Kusumawide, K. T., Saputra, W. N. E., Alhadi, S., \& Prasetiawan, H. (2019). Keefektifan Solution Focused Brief Counseling (SFBC) untuk menurunkan perilaku prokrastinasi akademik siswa. Counsellia: Jurnal Bimbingan Dan Konseling, 9(2), 89-102. https://doi.org/10.25273/counsellia.v9i2.4618

Komalasari, G., Wahyuni, E., \& Karsih. (2011). Teori dan Teknik Konseling. Jakarta: Indeks.

Latifah, L. (2019). Effectiveness of self management techniques to reduce truant students in middle school. Konselor, 8(1), 17. https://doi.org/10.24036/0201981103804-0-00.

Maile, S., \& Olowoyo, M. M. (2017). The Causes of Late Coming among High School Students in Soshanguve, Pretoria, South Africa. Pedagogical Research, 2(2), 111. https://doi.org/10.20897/pr/80951.

Moleong, L. J. (2016). Metodologi Penelitian Kualitatif. Bandung: Remaja Rosdakarya.

Mulyani, A. (2017). Peningkatan Kehadiran Siswa kelas XI Pemasaran 2 Menggunakan Konseling Perorangan Teknik Eklektik. Jurnal Konseling Dan Pendidikan, 5(3), 167. https://doi.org/10.29210/120000

Muratama, M. S. (2018). Layanan Konseling Behavioral Teknik Self Management Untuk Meningkatkan Disiplin Dan Tanggung Jawab Belajar Siswa Di Sekolah. Nusantara of Research: Jurnal Hasil-Hasil Penelitian Universitas Nusantara PGRI Kediri, 5(1), 1-8. https://doi.org/10.29407/nor.v5i1.11793

Nakpodia, E. D,. \& Dafiaghor, F. K. (2011). Lateness: A Major Problem Confronting School Administrators in Delta State, Nigeria. International Journal of Science and Technology Education Research Vol. 2 (4), 58-61. https://doi.org/10.5897/NGOJ11.011

Nurazmi, R., \& Kurniawan, K. (2016). Meningkatkan Motivasi Berprestasi Rendah Melalui Konseling Behavior Teknik Self Management. Indonesian Journal of Guidance and Counselling 5 (4) (2016), 26-32.

Nurzaakiyah, S,. \& Budiman, N. (2013). Teknik Self-Management Dalam Mereduksi Body Dysmorphic Disorder. Jurnal Psikologi Pendidikan dan Bimbingan, 13-39. 
Prabowo, A. S., \& Cahyawulan, W. (2016). Pendekatan Behavioral: Dua Sisi Mata Pisau. Insight: Jurnal Bimbingan Konseling, 5(1), 15-19. https://doi.org/10.21009/insight.051.03

Prayitno, \& Amti, E. (2004). Dasar-Dasar Bimbingan dan Konseling. Jakarta: Rineka Cipta.

Sa'diyah, H., Chotim, M., \& Triningtyas, D.A. (2016). Penerapan Teknik Self Management Untuk Mereduksi Agresifitas Remaja. Jurnal Ilmiah Counsellia, Volume 6 No. 2, November 2016, 67 - 78. https://doi.org/10.25273/counsellia.v6i2.1018

Sanyata, S. (2012). Teori dan Aplikasi Pendekatan Behavioristik dalam Konseling Jurnal Paradigma, No. 14 Th. VII, Juli 2012, 1-11.

Sugiyono. (2015). Metode Penelitian Kualitatif Kuantitatif dan $R \& D$. Bandung: Alfabeta. Suwanto, I. (2016). Konseling Behavioral Dengan Teknik Self Management Untuk Membantu Kematangan Karir Siswa SMK. JBKI (Jurnal Bimbingan Konseling Indonesia), 1(1), 1-5. https://doi.org/10.26737/jbki.v1i1.96

Thompson, R. (2016). Counselling Techniques: Improving Relathionships with Others, Ourselves, Our Families, and Our Environment. New York: Rouledge Taylor \& Francis Group.

Wahyaningrum, A., Muslim, M., \& Hidayat, R. R. (2017). Teknik Self Management untuk Meningkatkan Kemandirian Belajar Siswa MTs. Consilium: Jurnal Program Studi Bimbingan Dan Konseling, 5(2), 70-73.

Walker, J., \& Shea, T. M. (2010). Behavior Management a Practical Approach for Education. Columbus: Memil Publishing.

Willis, S. S. (2010). Konseling Individual : Teori dan Praktek. Bandung: Alfabeta.

Wolpe, J. (1963). Psychoterapy: The Nonscientific Hetitage and the New Science. Behav.Res 